\title{
VIRULENCE EXALTATION OF Clostridium perfringens STRAINS FROM BOVINES.
}

\section{BALDASSI L. ${ }^{\text {; }}$ BARBOSA M.L. ${ }^{2}$; BACH E.E. ${ }^{3}$; IARIA S.T. ${ }^{4}$}

${ }^{1}$ Seção de Bacteriologia Geral e Micobacterioses, Instituto Biológico; ${ }^{2}$ Instituto Adolfo Lutz; ${ }^{3}$ Instituto Biológico - UNICASTELO; ${ }^{4}$ Departamento de Microbiologia, Instituto de Ciências Biomédicas, Universidade de São Paulo (USP), São Paulo, Brasil.

\begin{abstract}
Ten out of eighty-nine strains biochemically identified as Clostridium perfringens, isolated from bovine organs, were selected by their different results showed in toxigenicity test on mice. Those and the standard strains, ATCC types A, B, C, and D, had their virulence exalted through serial intramuscular inoculation into guinea pigs.

Results showed that, for toxigenic strains (6), one or two passages were enough to cause exaltation, while for the atoxigenic (4), five or six inoculations were needed. Esterase electrophoresis of standard and isolated strains, with and without exaltation, was performed. Electrophoresis analysis permits the following conclusions: strains that do not show any clinical symptoms in mice, when exalted demonstrate decreased esterase activity; on the contrary, it is increased when correlated with animal symptoms.
\end{abstract}

KEY WORDS: Clostridium perfringens, bovine, electrophoresis, virulence exaltation.

CORRESPONDENCE TO: L. Baldassi - Laboratório de Bacteriologia Geral e Micobacterioses, Instituto Biológico. Avenida Conselheiro Rodrigues Alves, 1252, 04014002, São Paulo, SP, Brazil. E-mail: baldassi@biologico.sp.gov.br 


\section{INTRODUCTION}

Clostridia have little low invasive ability, and the pathogenicity of these bacteria is mainly determined by toxin production. From the species of this genus, C. perfringens is the most widely spread $(13,15,30)$. According to Willis (38), the predominance of the several types (A, $\mathrm{B}, \mathrm{C}$, and D) is not uniform, and type A is the most prevalent one; soil is believed to be its natural environment $(33,35,38)$. C. perfringens is also found in the feces of some animal species (35). The other types are predominantly related to the intestinal tract of animals, and their presence in soil is due to fecal contamination $(33,38)$.

C. perfringens produces several soluble antigens (toxins), and most of the studies focuses on the pathogenic effects they produce. However, the role each of the toxins has in the production of lesions and symptoms caused by this agent is not totally established, neither in men nor in animals $(24,25)$.

Different cases of acute enteritis or fatal enterotoxaemia have been reported in several animal species, such as sheep, cattle (20,21,31), pigs (12), dogs (9), and horses (26). Sudden death in ovine, bovines and caprines has also been attributed to C. perfringens $(3,27,34)$.

In the present trial, standard and isolated C. perfringens strains, from samples obtained in post-mortem examination of bovines, were submitted to virulence exaltation. Esteraseelectrophoretic profile of strains with and without exalted virulence was compared.

\section{MATERIAL AND METHODS}

\section{Sampling}

Ten from eighty-nine strains biochemically identified as C. perfringens, isolated from postmortem examination of 71 bovines, were selected by their different results showed in the toxigenicity test on mice (4).

As a positive control, four other C. perfringens strains from American Type Culture Collection (ATCC), ATCC 3624 (type A), ATCC 3626 (type B), ATCC 3628 (type C), and ATCC 3629 (type D), were used. 
L. Baldassi et al. VIRULENCE EXALTATION OF C. perfringens STRAINS FROM BOVINES. J. Venom. Anim. Toxins incl. Trop. Dis., 2004, 10, 3, p.282.

\section{Isolation and biochemical identification of C. perfringens in field samples}

Isolated and standard strains were cultured in Cooked Meat Medium (CMM) at $37^{\circ} \mathrm{C}$ for 18 24 hours and then kept at $4^{\circ} \mathrm{C}$. Three $\mu \mathrm{l}$ of this culture was streaked in a plate containing Brain Heart Infusion (BHI) agar, with 5\% of defibrinated sheep blood and incubated in anaerobiosis in McIntosh and Fields jars at $37^{\circ} \mathrm{C}$ for $18-24$ hours.

After incubation, colonies were analyzed according to the shape, color, production and type of hemolysis. Bacterial morphology was microscopically assessed in Gram-stained smears. Colonies presenting C. perfringens characteristics were isolated, cultured in CMM, and incubated at $37^{\circ} \mathrm{C}$ for $18-24$ hours. These cultures were submitted to the following biochemical tests for species identification: production of catalase, lecithinase and gelatinase, fermentation of glucose, lactose and skim milk. Interpretation was performed according to Holdeman and Moore (16); Mahony and Swantee (22); Mahony et al. (23).

All the strains of the present trial were incubated in CMM, and after 18-24 hours of incubation at $37^{\circ} \mathrm{C}$, cultures were stored at $4^{\circ} \mathrm{C}$.

\section{Toxigenicity of isolated strains}

Each bacterial isolate and standard strain was cultured in plates containing Brain Heart Infusion Blood (BHIB) agar, incubated in MacIntosh and Fields jars at $37^{\circ} \mathrm{C}$ for $18-24$ hours. Five colonies were transferred from these cultures (23) to tubes containing $10 \mathrm{~mL}$ of Tryptose Yeast Extract (TYE) broth, followed by incubation in the same conditions as described above. After incubation, all the contents of each tube was transferred to a flask containing $90 \mathrm{~mL}$ of the same medium, and incubated the same way (29). Culture morphology and purity was assessed in each step of the procedure, by Gram staining.

The final culture was then centrifuged at $7,500 \mathrm{xg}$ at $4^{\circ} \mathrm{C}$ for 15 minutes for cell debris removal. Supernatant was withdrawn and used in the determination of toxigenicity on mice.

The supernatant of each isolate or standard strain culture was intraperitonially inoculated into ten albino mice, weighting from 20 to $25 \mathrm{~g}$, in a dose of $0.5 \mathrm{~mL}$. Pure supernatant was injected into five mice, and the remaining animals received trypsin-treated supernatant, in a final concentration of $1 \%$, after incubation at $37^{\circ} \mathrm{C}$ for 30 minutes (2). Animals were observed for up to 96 hours in order to detect clinical signs or death. 


\section{Virulence exaltation}

Four isolates and ten standard strains presenting toxigenicity variations were submitted to virulence exaltation. They were cultured in CMM, and after $18-24$ hours at $37^{\circ} \mathrm{C}$, intramuscularly inoculated into the internal part of the hind legs of guinea pigs. By an incision in the previously wounded muscle, a fragment was collected and cultured in CMM. Successive passages were performed, until the administration of $0.1 \mathrm{~mL}$ inoculum of a 6-hour culture killed a guinea pig, weighting from 200 to 250 g, in 24 hours (19).

Sediments of exalted and non-exalted strains were washed in $100 \mathrm{~mL}$ of buffered tris-glycine solution $60 \mathrm{mM}$, pH 8.7, followed by centrifugation at $10,000 \mathrm{xg}$ at $4^{\circ} \mathrm{C}$ for 10 minutes. Cell mass of each isolate was suspended in $1.0 \mathrm{~mL}$ of the same buffer, grinded in a mortar containing liquid nitrogen, and centrifuged once more at $10,000 \mathrm{xg}$ at $4^{\circ} \mathrm{C}$ for 30 minutes (29). From the sediment obtained in the last centrifugation, aliquots of about $1 \mathrm{~mL}$ were withdrawn and kept at $-20^{\circ} \mathrm{C}$ until submitted to electrophoresis.

\section{Electrophoretic analysis}

Estimated protein concentration was determined by the Bradford method (6), using bovine albumin V as standard protein. Readings were performed in a microplate reader (BIO-RAD, model 3550-UV) connected to a computer with Microplate Manager software.

Sediments were applied to a polyacrylamide gel, in $18 \mu \mathrm{L}$ of $7 \%$ acrylamide/bis-acrylamide, corresponding to $250 \mu \mathrm{g}$ of proteins. Tris-glycine buffer $\mathrm{pH} 8.2-0.1 \mathrm{M}$ was used both in the preparation of the gel and in the analysis (5).

The gel was stained with a solution containing Fast Blue substrate and $\alpha$-naftil acetate for 60 minutes, kept in distilled water for complete removal of the substrate, and dehydrated in a drier (BIO-RAD, model 583). Reading was performed in a densitometer (BIO-RAD, model GS-700) connected to a microcomputer and analysed by Molecular Analyst software. 


\section{RESULTS}

\section{Biochemical characterization of the strains}

Eighty-nine strains were biochemically identified as $C$. perfringens, due to the production of catalase, lecithinase and gelatinase, and to the fermentation of glucose, lactose and irregular fermentation of skim milk.

\section{Toxigenicity determination}

From the 89 strains tested, 51 (57.3\%) have shown to be toxin-producers. Fourteen of them were toxigenic (15.7\%) only when the supernatant was in the untreated form, 8 (9.0\%) only after trypsin treatment, and 29 (32.6\%) in both forms. Thirty-eight (42.7\%) strains did not kill any mice and were considered to be atoxigenic (Table 1).

\section{Characterization and analysis of esterase electrophoretic profile}

In the densitometry of electrophoretic mobility $(\mathrm{Rm})$, standard strains $\mathrm{A}, \mathrm{B}$ and $\mathrm{D}$ presented only one band each, between 1.7 and $3.2 \mathrm{~cm} ; 3.0$ and $4.8 \mathrm{~cm}$; and 2.5 and $6.0 \mathrm{~cm}$, respectively. Standard strain C presented two bands, one between 1.5 and $3.5 \mathrm{~cm}$, and the other between 3.5 and $5.4 \mathrm{~cm}$. The 89 strains selected were classified using these $\mathrm{Rm}$ as parameters (5).

\section{Virulence exaltation}

The 10 strains selected in the toxigenicity assay presented the following variation: two of them were toxigenic before and after trypsin treatment; two were atoxigenic only without treatment; two were toxigenic only after treatment, and four did not show to be toxigenic in neither forms (Table 1). The inoculation of these strains into guinea pigs showed that for strains that were already toxigenic, one or two passages were enough to cause virulence exaltation, while the atoxigenic ones only showed pathogenicity after five or even six passages.

Electrophoresis of the standard strains type A and D produced bands similar in the original form and with exalted virulence. Strain type B presented three bands and type C only one band, while the original form presented two bands (Figure 1). The bands volume densitograms percentiles, bands areas, mean absorbance, and relationship absorbance $\mathrm{X}$ area 

incl. Trop. Dis., 2004, 10, 3, p.285.

of strains in their original form and exalted are presented in Figure 2.

Exalted strains that were totally atoxigenic or did not show any clinical symptom demonstrated decrease in the esterase activity when compared to not exalted strains. On the contrary, when clinical symptoms are present, the activity of esterase was higher in exalted strains (Figure 3).

\section{DISCUSSION}

Disease and death in herds pose potential risks to public health. Economic losses are estimated in $17 \%$ of the production costs in developed countries, and more than twice as this for developing ones. Diseases caused by clostridia are, up until today, a great economic problem in Brazil. When vaccination schemes are strictly followed, these diseases may be adequately controlled. However, deaths caused by C. perfringens, mainly in bovine herds, are responsible for great losses by cattle producers, decreasing meat exports and protein availability to the population. Most of the times, the cause of these deaths is not determined, or when it is, diagnosis is restricted to bacterial genus and species, without type identification. In veterinary practice, diagnosis of enterotoxaemia is based on history, clinical signs, and findings in the post-mortem examination. However, laboratory analyses are essential to confirm the presence of toxins (34). In some cases, toxigenic strains found in bacterial cultures of recently collected clinical samples are confirmatory proofs.

In general, detection of $C$. perfringens toxins in feces samples by the assay in mice is the standard confirmatory diagnostic test. However, tests performed in sheep detected low levels of $\varepsilon$ toxin in healthy and immunized animals (8). Both enterotoxin and $\varepsilon$ toxin have their toxic activity increased when treated with trypsin $(14,28,37)$, while $\beta$ toxin is inactivated by the same treatment (11). This may explain the finding in the present study of $9 \%$ toxigenic strains only after trypsin treatment and $15.7 \%$ strains that lost their toxigenicity after the treatment, as observed in Table 1.

The inoculation of supernatants from cultures of isolated strains into mice (Table 1) showed the presence of toxins; however, their types were not identified. From the 89 strains isolated, 

incl. Trop. Dis., 2004, 10, 3, p.286.

51 (57.3\%) were toxin producers and, therefore, potentially pathogenic. This result is in accordance with those obtained by Tsai et al., (36), who observed, in Canada, 60\% of toxigenicity in C. perfringens strains isolated from samples of bovines from slaughterhouse.

According to Holliday (17), the degree of encapsulation is associated with pathogenicity, since stronger reactions were observed with clinical isolates than with fecal or environmental strains. Strains kept for long periods in laboratory or those that have undergone many passages in artificial media lost their capsule and became uneven (18). These observations, in the present trial, justify the occurrence of toxigenic and atoxigenic strains in different organs of the same animal and the fact that atoxigenic strains started to present toxigenicity after their virulence exaltation. In relation to enterotoxin production, it was demonstrated that the strain ability of producing toxin in vitro does not reflect its ability to produce it in vivo. However, cultures kept under the same conditions may determine the strain toxigenic potential (23).

The existence of atoxigenic variants or variants that lose their toxicity should be considered $(7,10)$, as well as the fact that serological tests for toxins do not show a clear separation between the several types of $C$. perfringens (32).

Analysis of proteins and enzymatic standards by electrophoresis is a valuable method for the determination of genetic and physiological compounds in the host, and in vegetal or animal pathogens $(1,29)$. In this case, electrophoresis was done after exaltation to verify if the increasing toxigenicity of esterase activity would be altered. The results obtained in this work permit the following conclusion: strains that do not show any clinical symptom in mice, when exalted, have their esterase activity decreased; on the contrary, this activity is increased when correlated with animal symptoms. It must be pointed out, however, that the results of this study should be carefully considered due to the small number of strains tested. 

incl. Trop. Dis., 2004, 10, 3, p.287.

Table 1. Tripsinizated and non-tripsinizated supernatans toxigenicity of 89 isolated C.perfringens strains from bovine origin.

\begin{tabular}{|c|c|c|c|c|c|}
\hline $\begin{array}{l}\text { Sample } \\
\text { number }\end{array}$ & $\begin{array}{c}\text { Supernatant } \\
\text { without } \\
\text { tripsinization }\end{array}$ & $\begin{array}{l}\text { Supernatant } \\
\text { tripsinizated }\end{array}$ & $\begin{array}{c}\text { Sample } \\
\text { number }\end{array}$ & $\begin{array}{l}\text { Supernatant } \\
\text { without } \\
\text { tripsinization }\end{array}$ & $\begin{array}{l}\text { Supernatant } \\
\text { tripsinizated }\end{array}$ \\
\hline 1 & + & + & 46 & - & - \\
\hline 2 & + & + & 47 & - & - \\
\hline 3 & - & - & 48 & + & - \\
\hline 4 & - & - & 49 & - & - \\
\hline 5 & + & + & 50 & - & - \\
\hline 6 & - & - & 51 & - & - \\
\hline 7 & + & - & 52 & - & - \\
\hline 8 & - & - & 53 & - & - \\
\hline 9 & - & - & 54 & - & - \\
\hline 10 & + & + & 55 & - & - \\
\hline 11 & - & + & 56 & - & - \\
\hline 12 & - & - & 57 & - & - \\
\hline 13 & + & + & 58 & - & - \\
\hline 14 & + & + & 59 & + & - \\
\hline 15 & + & + & 60 & + & + \\
\hline 16 & + & + & 61 & - & - \\
\hline 17 & + & - & 62 & - & - \\
\hline 18 & + & - & 63 & + & - \\
\hline 19 & + & + & 64 & + & - \\
\hline 20 & - & - & 65 & - & + \\
\hline 21 & - & - & 66 & - & - \\
\hline 22 & + & + & 67 & + & - \\
\hline 23 & - & - & 68 & + & - \\
\hline 24 & + & + & 69 & + & - \\
\hline 25 & + & + & 70 & - & + \\
\hline 26 & + & - & 71 & + & + \\
\hline 27 & - & - & 72 & - & - \\
\hline 28 & + & + & 73 & - & - \\
\hline 29 & + & + & 74 & + & + \\
\hline 30 & + & + & 75 & + & + \\
\hline 31 & + & + & 76 & + & + \\
\hline 32 & - & - & 77 & - & - \\
\hline 33 & - & - & 78 & - & - \\
\hline 34 & + & + & 79 & - & - \\
\hline 35 & - & + & 80 & + & + \\
\hline 36 & + & + & 81 & - & - \\
\hline 37 & - & + & 82 & - & - \\
\hline 38 & + & + & 83 & - & - \\
\hline 39 & + & - & 84 & + & + \\
\hline 40 & + & - & 85 & - & - \\
\hline 41 & - & - & 86 & - & - \\
\hline 42 & + & + & 87 & + & + \\
\hline 43 & - & + & 88 & - & + \\
\hline 44 & + & - & 89 & - & + \\
\hline 45 & + & + & & & \\
\hline
\end{tabular}




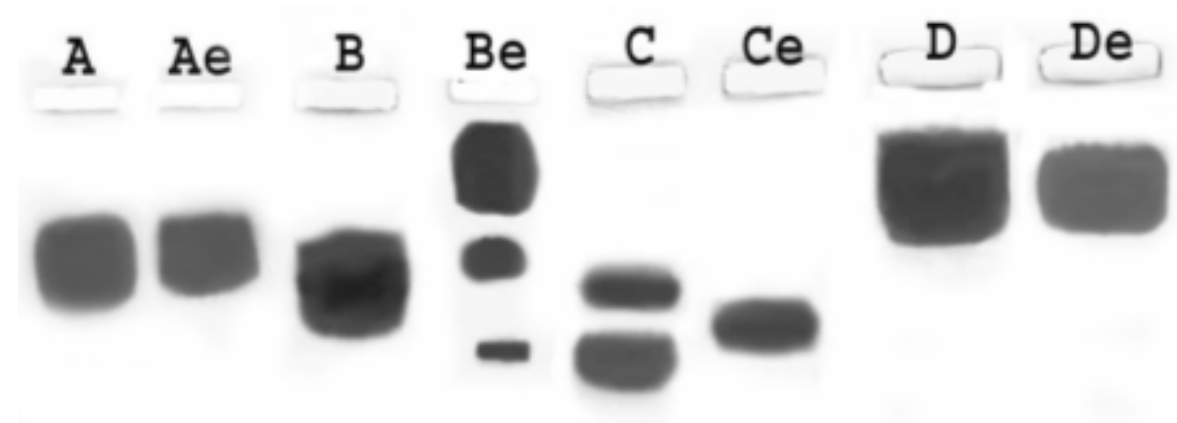

Figure 1. Polyacrilamide gel stained for esterase - electrophoretic analysis of ATCC C. perfringens strains 3624 type A; 3626 type B; 3628 type C, and 3629 type D, normal and exalted (Ae, Be, Ce, De).
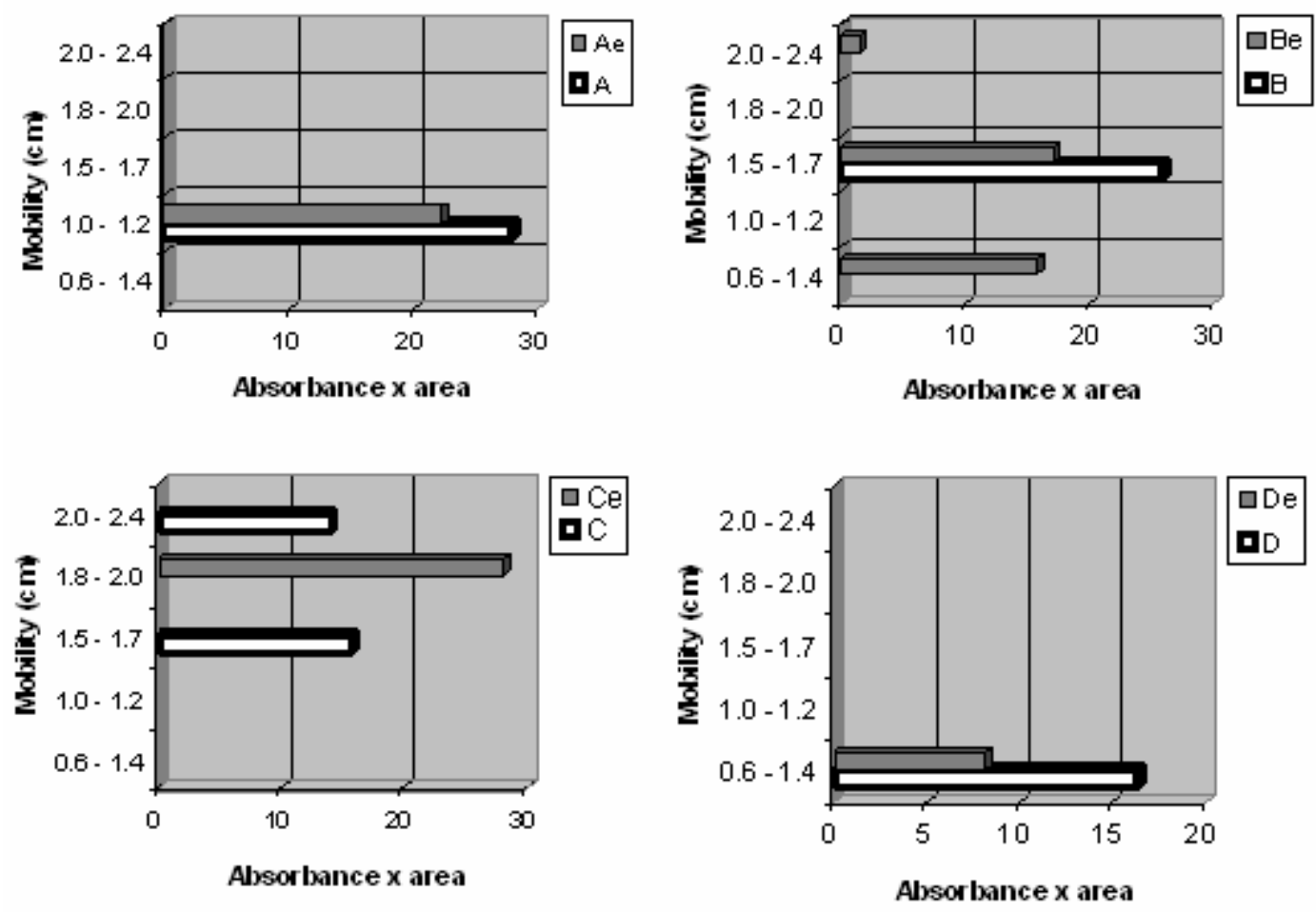

Figure 2. Mobility $(\mathrm{cm})$ of esterase bands correlated with absorbance and area of ATCC C. perfringens strains 3624 type A; 3626 type B; 3628 type C, and 3629 type D, normal and exalted (Ae, Be, Ce, De). 

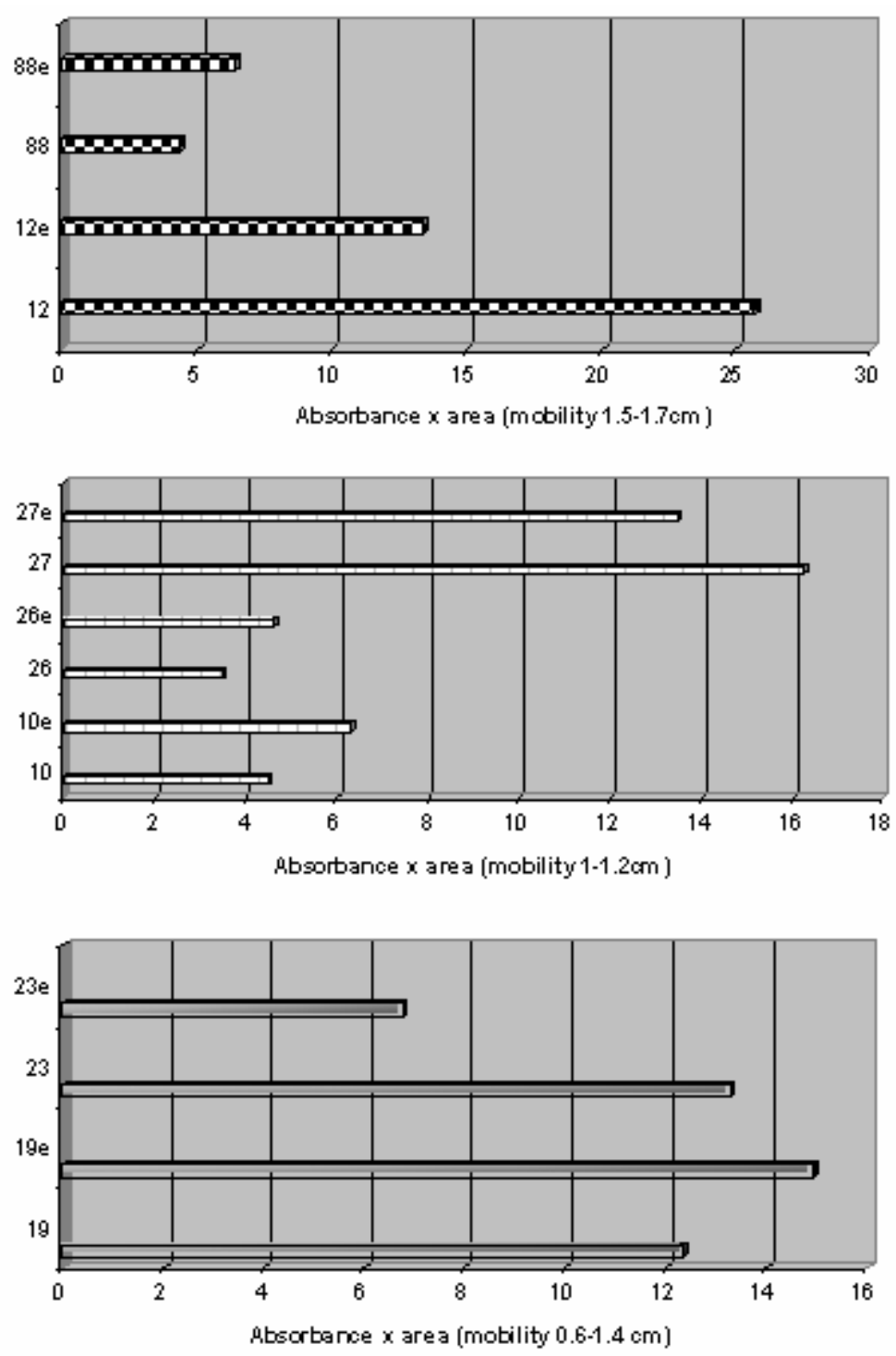

Figure 3. Absorbance $\mathrm{x}$ area correspondent to mobility $(\mathrm{cm})$ of esterase bands of $C$. perfringens strain 10, 26, 27 type A; 88, 12 type B; 23, 19 type D, normal and exalted (10e, 26e, 27e, 88e, 12e, 23e, 19e).

\section{REFERENCES}

1 ALFENAS AC., JENG R., HUBBES M. Isoenzyme and protein patterns of isolates of Cryphonectria cubensis differing in virulence. Can. J. Bot., 1984, 62, 1756-62.

2 BALDASSI L. Isolamento de bactérias do gênero Clostridium e detecção de toxina botulínica a partir de materiais obtidos de bovinos com suspeita clínica de botulismo. 
L. Baldassi et al. VIRULENCE EXALTATION OF C. perfringens STRAINS FROM BOVINES. J. Venom. Anim. Toxins incl. Trop. Dis., 2004, 10, 3, p.290.

São Paulo: Universidade de São Paulo, Faculdade de Saúde Pública, 1986. 59p.

[Dissertação - Mestrado].

3 BALDASSI L., CALIL EMB., PORTUGAL MASC., MOULIN AAP., MOURÃO MAF.

Morte súbita de caprinos por enterotoxemia. Braz. J. Vet. Res. Anim. Sci., 1995, 32, 109-13.

4 BALDASSI L., BARBOSA ML., BACH EE., IARIA ST. Toxigenicity characterization of Clostridium perfringens from bovine isolates. J. Venom. Anim. Toxins incl. Trop. Dis., 2002, 8, 112-26. (SciELO)

5 BALDASSI L., BARBOSA ML., BACH EE., IARIA ST. Esterase electrophoresis of Clostridium perfringens bovine strains. J. Venom. Anim. Toxins incl. Trop. Dis., 2003, 9, 277-90. (SciELO)

6 BRADFOD MM. A rapid and sensitive method for the quantitation of microgram quantities of protein utilizing the principle of protein-dye binding. Anal. Biochem., 1976, 72, 24854.

7 BUDDLE MB. Degraded strains of Clostridium welchii type C isolated from sheep in New Zeland. J. Comp. Pathol. Ther., 1954, 64, 223-4.

8 BULLEN JJ. Role of toxins in host-parasite relationships. In: AJL. SJ., KADIS S., MONTIE TC. Mocrobial toxins. New York: Academic Press, 1970: 233-76.

9 CARMAN RJ. Recurrent diarrhoea in a dog associated with Clostridium perfringens type A. Vet. Rec., 1983, 112, 342-3.

10 DALLING T., ROSS HE. Clostridium welchii. Notes on the relationship between the types of cultures and the production of toxin. J. Comp. Pathol. Ther., 1938, 51, 235-49.

11 DOWELL VR., HAWKINS TM. Laboratory methods in anaerobic bacteriology: CDC laboratory manual. Washington: U.S. Governm. Print. Office. 1974. ( D.H.E.W. Publ. $n^{\mathrm{o}}$ 74-8272 ).

12 ESTRADA A., BACA ME., TAYLOR D. Sporulation and enterotoxin production by mutants of Clostridium perfringens type A strains isolated from pig diarrhoea. Rev. Latinoam. Microbiol., 1989, 31, 45-50. 
L. Baldassi et al. VIRULENCE EXALTATION OF C. perfringens STRAINS FROM BOVINES. J. Venom. Anim. Toxins incl. Trop. Dis., 2004, 10, 3, p.291.

13 ESTY JR. The biology of Clostridium welchii. J. Bacteriol., 1920, 5, 375-429.

14 GRANUM PE., WHITAKER JR., SKJELKVALE R. Trypsin activation of enterotoxin from spores of Clostridium perfringens type A. Biochim. Biophys. Acta, 1981, 668, 325-32.

15 HATHEWAY CL. Toxigenic clostridia. Clin. Microbiol. Rev., 1990, 3, 66-98.

16 HOLDEMAN LV., MOORE WEC. Anaerobic Laboratory Manual. 3 ed. Virginia:

Virginia Polytechnic Institute and State University, 1972. 132 p.

17 HOLLIDAY MG. Rapid identification of Clostridium perfringens by counterimmunoelectrophoresis. Med. Lab. Sci., 1985, 42, 322-5.

18 HUGHES JA., TURNBULL PCB., STRINGER MF. A serotyping system for Clostridium welchii (C. perfringens) type A, and studies on the type-specific antigens. $\boldsymbol{J}$. Med. Microbiol., 1976, 9, 475-84.

19 LOGAN MA., TYTELL AA., DANIELSON IA., GRINER AM. Production of Clostridium perfringens alpha toxin. J. Immunol., 1945, 51, 317-28.

20 MACKAY NNS., GRUNEBERG RN., HARRIES BJ., THOMAS PK. Primary Clostridium welchii meningitis. Br. Med. J., 1971, 1, 591-2.

21 MACRAE DR., MURRAY EG., GRANT JG. Entero-toxemia in young suckled calves. Vet. Rec., 1943, 30, 305-6.

22 MAHONY DE., SWANTEE CA. Bacteriocin typing of Clostridium perfringens in human feces. J. Clin. Microbiol., 1978, 7, 307-9.

23 MAHONY DE., AHMED R., JACKSON SG. Multiple typing techniques applied to a Clostridium perfringens food poisoning outbreak. J. Appl. Bacteriol., 1992, 72, 30914.

24 McDONEL JL. Clostridium perfringens toxins (type A, B, C, D, E). Pharmacol. Ther., 1980, 10, 617-55.

25 McDONEL JL. Toxins of Clostridium perfringens types A, B, C, D and E. In: DORNER F., DREWS J. Pharmacology of bacterial toxins. New York: Pergamon, 1986: 477517. 
L. Baldassi et al. VIRULENCE EXALTATION OF C. perfringens STRAINS FROM BOVINES. J. Venom. Anim. Toxins incl. Trop. Dis., 2004, 10, 3, p.292.

26 NIILO L. Clostridium perfringens in animal disease a review of current knowledge. Can. Vet. J., 1980, 21, 141-8.

27 NIILO L., AVERY RJ. Bovine enterotoxemia I. Clostridium perfringens types isolated from animal sources in Alberta and Saskatchewan. Can. Vet. J., 1963, 4, 31-6.

28 OAKLEY CL., WARRACK GH. Routine typing of Clostridium welchii. J. Hyg. (Cambridge), 1953, 51, 102-7.

29 PONS JL., PICARD B., NIEL P., LELUAN G., GOULLET P. Esterase electrophoretic polymorphism of human and animal strains of Clostridium perfringens. Appl. Environ. Microbiol., 1993, 59, 496-501.

30 ROOD JI., COLE ST. Molecular genetics and pathogenesis of C. perfringens. Microbiol. Rev., 1991, 55, 621-48.

31 ROSE AL., EDGAR G. Enterotoxemia jaundice of sheep and cattle. Aust. Vet. J., 1936, 12, 212.

32 SERRANO AM., SCHNEIDER IS. New modification of Willis and Hobbs' method for identification of Clostridium perfringens. Appl. Environ. Microbiol., 1978, 35, 80910.

33 SMITH LDS. The pathogenic anaerobic bacteria. Springfield: Charles C. Thomas Publ., 1975. 430p.

34 STERN M., BATTY I. Pathogenic clostridia. London: Butterworths, 1975. 144p.

35 TAYLOR AW., GORDON WS. A survey of the types of $C$. welchii present in soil and in the intestinal contents of animals and man. J. Pathol. Bacteriol.,1940, 50, 271-7.

36 TSAI CC., TORRES-ANJEL MJ., RIEMANN HP. Characteristics of enterotoxigenic Clostridium perfringens type A isolated from cattle and chickens. J. Formosan Med. Assoc., 1974, 73, 501.

37 UEMURA T., NAKAHARA H., HORIGUCHI Y., SAKAGUCHI G. Trypsinization of derivatives of C. perfringens enterotoxin. Lett. Appl. Microbiol.,1986, 3, 31-3.

38 WILLIS AT. Clostridia of wound infection. London: Butterworths, 1969. 156p. 